INTERNATIONAL JOURNAL OF MULTIDISCIPLINARY RESEARCH AND ANALYSis

ISSN(print): 2643-9840, ISSN(online): 2643-9875

Volume 04 Issue 08 August 2021

DOI: 10.47191/ijmra/v4-i8-07, Impact Factor: 6.072

Page No.- 1102-1105

\title{
Use of Basic Technological Devices and Student's Academic Performance
}

\author{
Mildred A. Lozano ${ }^{1}$, Rexomar D. Perez ${ }^{2}$ \\ ${ }^{1}$ Teacher III, Department of Education, Victorias National High School, Philippines \\ ${ }^{2}$ Teacher II, Department of Education, Victorias National High School, Philippines \\ Corresponding Authors: Judy Ann Adolfo ${ }^{1}$, Glyza Joy Dequito ${ }^{2}$, Paula Joy Pasco ${ }^{3}$, Danna Marie Rubinos ${ }^{4}$ \\ 1,2,3,4 Victorias National High School
}

ABSTRACT: Technology has always flourished for the gain of mankind. Broadly speaking, all cellular phones, laptops and computers belong to technological devices. Thus, students used these devices for learning. This quantitative inquiry investigated the use of technological devices of students and its relationship to their academic performance. Hence, a researcher-made questionnaire was utilized to answer the descriptive and inferential questions. It was found out that there is no significant difference between the use of technological devices and the academic performance of students. But there was a significant relationship found between the two variables. A recommendation on the use of both traditional method and use of technological devices was made to augment and improve the learning needs of the students.

KEYWORDS: Technology, students, academic performance, quantitative, Philippine

\section{INTRODUCTION}

Technological devices (TD) have been anticipated as beneficial tool for learning. In education, TD are rapidly adopted. These devices were used often to schools without considering its effect on learning. Also, there is a limited understanding of values and ways that these devices benefit learning and how to effectively use it in education. Thus, there is a need to construct a digital ecology to have a cohesive learning experience (Yee, Quek, Chung, \& Sawyer, 2012). Mobile learning is rapidly spreading but the eventual consequence of it is not yet clear. It also becomes the most efficient way for instruction delivery. Thus, it is necessary to examine its implication in teaching and learning (El-Hussein \& Cronje, 2010) since previous studies have shown that it helped students improve their learning (Halili, Nurul \& Rafiza, 2018; Halili \& Suguneswary, 2016; Halili \& Hamidah, 2016; Maryam \& Halili, 2015).

In Singapore, there is an increase accessibility and availability of technological devices. Concerns from parents was raised on the risks and benefits of the devices to young children since they have access to it daily. Children have been the remote controlled by the devices which undermine their abilities to create learning (Ebbeck, Yim, Chan, \& Go, 2016). Also, in Tripura private schools, they provide learning environments to students. Their schools have well- trained teachers, laboratories, and other equipment. But in their capital city (Agartala), the availability and usability of educational technology is not more satisfactory (Biswas, 2014). Also, in Malaysia, they embrace the fourth industrial revolution to revamp the Malaysian education system. They have digital integration in their everyday lives where they aligned themselves to machines to discover new theory of innovation that made teaching and learning process dynamic (Ali, 2017).

The evolution of wireless technology and other devices has radically changed the social and economic lifestyle of the people. These devices have reshaped people in different ways but only a few have regarded it for learning. Devices are primarily popular because its wireless and portable. It enables users to communicate while on the move. Thus, it consequently added to their ability for multiple level functions. Visionary educators should begin to consider the implications of these devices in modern teaching and learning process. Thus e-learning will take place to those who are familiar with it. Emergence of technology has significant impact in education. It eliminates the fixity of traditional classroom, and it does not have to be confined in one place to be effective (El-Hussein \& Cronje, 2010). 


\section{Use of Basic Technological Devices and Student's Academic Performance}

The use of technological aids has been an integral part in education (Biswas, 2014), it can enhance teaching and learning process that creates interest to learners to participate (Ali, 2017) and help students understand effectively the learning contents aside from the use of traditional approach (Halili, 2019). Modern teachers use technological advances to vitalize the learning process. The development of multimedia technology is in full play in class teaching to reform and explore teaching model in new era. It proved a positive role in promoting activities in class. Therefore, teachers should be fully aware and have knowledge on the latest and best equipment since in the present educational system, technological devices are important items in school curriculum (Biswas, 2014) and students are more favour in using technology (Halili, 2019).

\section{METHODS}

A simple survey was utilized in this study. A descriptive- correlational research design is used to collect information to provide answers of a particular study (Prieto, Naval and Carey, 2018). A sample of 84 out of 147 Humanities and Social Sciences Stand students of Victorias National High School in Victorias City during the School Year 2018- 2019 were taken as respondents of the study utilizing the stratified random sampling (Monge \& Perez, 2021). The respondents identified the technological devices they used to augment learning and they were asked to give their academic grades based on their class report cards. Moreover, they were classified according to variable of sex. Hence, their academic performance was categorized using the Department of Education standards: Outstanding, Very Satisfactory, Satisfactory, Fairly- Satisfactory, and Did Not Meet Expectations.

A self-made survey-instrument was used in gathering data. It was further validated by jurors using the Good and Skates validation form with a 4.50 validity index. The instrument includes the demographic data of students including their sex, and academic grades for the school year. Hence, reliability testing follows (Monge \& Perez, 2021) with a Cronbach's alpha of 0.864 . Therefore, the instrument used was both valid and reliable. The data were statistically analysed using a frequency count the number of users of the technological devices and the academic performances of the students. Consequently, Mann- Whitney $U$ Test and Kruskal-Wallis was utilized to test if there is significant difference between use of technologies to their sex, and academic performance. Lastly, Chi-square test was utilized to determine if there was a significant relationship on the use of technological devices and their academic performance considering that the data are non- parametric.

\section{RESULTS AND DISCUSSION}

It is evident that there were 26 male and 58 female who responded to the actual survey. Also, all respondents have use in technological devices such as cell phone, laptop, personal computer, and tablet. Likewise, the academic performance of the students ranges from fairly satisfactory to outstanding. Thus, all students are considered passed. The descriptive data are presented below.

Table 1: Frequency Table for Sex

\begin{tabular}{|l|l|l|l|l|l|}
\hline & & Frequency & Percent & Valid Percent & Cumulative Percent \\
\hline \multirow{4}{*}{ Valid } & male & 26 & 31.0 & 31.0 & 31.0 \\
\cline { 2 - 6 } & female & 58 & 69.0 & 69.0 & 100.0 \\
\cline { 2 - 6 } & Total & 84 & 100.0 & 100.0 & \\
\hline
\end{tabular}

Table 2: Frequency Table for Technological Devices

\begin{tabular}{|l|l|l|l|l|l|}
\hline & & Frequency & Percent & Valid Percent & Cumulative Percent \\
\hline Valid & cellphone & $\mathbf{7 6}$ & 90.5 & 90.5 & 90.5 \\
\cline { 2 - 6 } & laptop & 5 & 6.0 & 6.0 & 96.4 \\
\cline { 2 - 6 } & PC & 2 & 2.4 & 2.4 & 98.8 \\
\cline { 2 - 6 } & tablet & 1 & 1.2 & 1.2 & 100.0 \\
\cline { 2 - 6 } & Total & 84 & 100.0 & 100.0 & \\
\hline
\end{tabular}

Table 3: Frequency Table for Academic Performance

\begin{tabular}{|l|l|l|l|l|l|}
\hline & & Frequency & Percent & Valid Percent & Cumulative Percent \\
\hline \multirow{3}{*}{ Valid } & Outstanding & 49 & 58.3 & 58.3 & 58.3 \\
\cline { 2 - 6 } & VS & 28 & 33.3 & 33.3 & 91.7 \\
\cline { 2 - 6 } & Satisfactory & 5 & 6.0 & 6.0 & 97.6 \\
\hline
\end{tabular}


Use of Basic Technological Devices and Student's Academic Performance

\begin{tabular}{|l|l|l|l|l|l|}
\hline & FSatisfactory & 2 & 2.4 & 2.4 & 100.0 \\
\cline { 2 - 6 } & Total & 84 & 100.0 & 100.0 & \\
\hline
\end{tabular}

The data also showed that there was no significant difference between the use of technological devices and sex of students. Likewise, there was no significant difference on the use of technological devices and students' academic performance. It is understood that the variables are very independent that it does not affect one another. The data specification is presented below.

Table 4: Significant difference between Technological Devices and Sex

\begin{tabular}{|l|l|}
\hline & TD \\
\hline Mann-Whitney U & 731.000 \\
\hline Wilcoxon W & $1.082 \mathrm{E} 3$ \\
\hline Z & -.437 \\
\hline Asymp. Sig. (2-tailed) & .662 \\
\hline a. Grouping Variable: Sex \\
\hline
\end{tabular}

Table 5: Significant difference between Technological Devices and Academic Performance

\begin{tabular}{|l|l|}
\hline & AcadPerf \\
\hline Chi-Square & 1.585 \\
\hline df & 3 \\
\hline Asymp. Sig. & .663 \\
\hline a. Kruskal Wallis Test \\
\hline b. Grouping Variable: TD \\
\hline
\end{tabular}

Lastly, it was found out that the use of technological devices of students are significantly related to their academic performance. Thus, the use of TD can improve the student's academic performance knowing that all respondents have used TD for learning. The date is shown below.

Table 6: Significant relationship between Technological Devices and Academic Performance

\begin{tabular}{|l|l|l|}
\hline & TD & AcadPerf \\
\hline Chi-Square & $1.925 \mathrm{E2}^{\mathrm{a}}$ & $69.048^{\mathrm{a}}$ \\
\hline df & 3 & 3 \\
\hline Asymp. Sig. & .000 & .000 \\
\hline a. 0 cells (.0\%) have expected frequencies less than 5. The minimum expected cell frequency is 21.0. \\
\hline
\end{tabular}

\section{SUMMARY OF FINDINGS}

The students used technological devices as a tool for their learning. But there was no significant difference between students' sex and their use of technological devices. Additionally, students' academic performance and their use of technological devices do not affect to each other since there were no significant difference found. On the other hand, a significant relationship was found on the student's use of technological devices and their academic performance.

\section{CONCLUSIONS}

The results of the study on the use of technological devices and students' academic performance revealed that there was no significant difference between students' sex and their use of technological devices. Therefore, the sex has no effect on the use of technological devices of students. Furthermore, the findings showed that there is a relationship between the use of technological devices and students' academic performance. This means that technological devices have an impact to the academic performance of the students. 


\section{Use of Basic Technological Devices and Student's Academic Performance \\ RECOMMENDATIONS}

With the findings of this research that sex as a variable that has no effect on the use of technological devices of students and that technological use of devices can affect the academic performance, the researchers wanted to express recommendations to the following:

To the learning institutions, that they will integrate an ICT-based instruction in all the subjects as a tool to make learning easy and fast to all their students that aim to improve their academic performance.

To the teachers, that they must update their knowledge and skills in the use of advance technological devices and since these devices could be now an important instrument in the delivery of the curriculum.

To the parents, that they must try to provide their children with technological devices not just for playing or gaming but to encourage them to use these for their education.

To the students, with discipline and limitations, they are encouraged to explore the use of these technological devices to gain a positive impact on their academic performance.

Lastly, the researchers also hope that the results of this study would be of great help to other researchers and other people who would be interested to study on a specific technological device and academic performance.

\section{ACKNOWLEDGMENT}

All the glory and honour are offered to the almighty who were the source of strength of the researchers to continually explore education as whole that would impact its practices. Also, to the Department of Education, Division of Negros Occidental, Victorias National High School administration, teachers, and staff who is in one way or another became the support group of the researchers to pursue this study.

\section{REFERENCES}

1) BISWAS, M. (2014). A Study on the Technological Devices used by English Teachers at the Secondary level in Private Institutions in the capital city Agartala.

2) Ebbeck, M., Yim, H. Y. B., Chan, Y., \& Goh, M. (2016). Singaporean parents' views of their young children's access and use of technological devices. Early Childhood Education Journal, 44(2), 127-134.

3) El-Hussein, M. O. M., \& Cronje, J. C. (2010). Defining mobile learning in the higher education landscape. Journal of Educational Technology \& Society, 13(3), 12-21.

4) Halili, S. H. (2019). Technological advancements in education 4.0. The Online Journal of Distance Education and eLearning, 7(1), 63-69.

5) Yee, S. L. C. Y., Quek, F., Endert, A., Chung, H., \& Sawyer, B. (2012, July). The physicality of technological devices in education: building a digital experience for learning. In 2012 IEEE 12th International Conference on Advanced Learning Technologies (pp. 579-581). IEEE. 